\title{
TOXICITY OF SOME CONVENTIONAL AND NONCONVENTIONAL INSECTICIDES AGAINST COTTON LEFWORM, Spodoptera littoralis (BOISD.)
}

Saleh, A. A. ${ }^{1}$; Laila R. Elgohary ${ }^{1}$; W. M. Watson ${ }^{2}$ and

A. S. Elabassy ${ }^{2}$

1- Pesticides Dept., Fac. of Agric., Mansoura Univ., Egypt

2- Sakha Agric. Res. Station, Plant Protection Research Institute, ARC, Egypt

\begin{abstract}
The ovicidal action of three novel compounds (emamectin benzoate, methoxyfenozide, pyridalyl) and conventional insecticide (methomyl) against (0-24, 24-48 and 48-72 hours age) eggs of Spodoptera littoralis was assessed. The toxic activity of emamectin benzoate, methoxyfenozide, pyridalyl and methomyl against $4^{\text {th }}$ instar larvae of laboratory and field strains of $S$. littoralis were carried out. Also, the build up of resistance of each tested compound in the field strain was calculated. The joint toxic action of emamectin benzoate, methoxyfenozide and pyridalyl with tested insecticides was also studied. The obtained data revealed that emamectin benzoate gave an ovicidal activity higher than methomyl, methoxyfenozide and pyridalyl. Also, emamectin benzoate was a superior potent compound against $4^{\text {th }}$ instar larvae of $S$. littoralis followed by methoxyfenozide, with $\mathrm{LC}_{50}$ values were 0.007 and $0.932 \mathrm{ppm}$ after $72 \mathrm{hrs}$, while methomyl was the least toxic one, $L C_{50}$ value was $95.60 \mathrm{ppm}$. The build up of resistance of tested compounds indicated that the resistance ratio of methoxyfenozide and methomyl were 5.9 and 5.8 fold as the laboratory strain, while the resistance ratio of emamectin benzoate and pyridalyl were 2.7 and 1.9 fold as the laboratory strain. In respect with the joint toxic action, the all mixtures of the tested insecticides showed highly antagonisms effect as calculated by the co-toxicity factors. The present study suggests that emamectin benzoate is very effective in the control of S. littoralis.
\end{abstract}

Keywords: Cotton leafworm, ovicidal activity, larvicidal activity, joint toxic action, insecticides.

\section{INTRODUCTION}

The cotton leafworm, Spodoptera littoralis (Boisd) is one of the major insect pests that cause a considerable damage to many of the important vegetables and field crop in Egypt. The rising consumption of currently used insecticides in developing countries has led to a number of problems such as insect resistance, environmental pollution and the health hazards associated with pesticide residues. It is necessary to complement our reliance on synthetic pesticides with less hazardous, safe and biodegradable substitutes. Emamectin benzoate is a modified isolation of the soil microorganism, Streptomyces avermitilis. It affects the nervous system of arthropods by increasing chloride ion flux at the neuromuscular junction, resulting in cessation of feeding and irreversible paralysis. Also, it affects on GABA and glutamate-gated chloride channel agonist (Dunbar et al., 1998).

Methoxyfenozide is classified as a diacylhydrazine insecticide. It acts as ecdysone agonists with enormous potential for development as insect 
specific control agents with little or no effect on non-target species (Dhadialla and Carlson, 1998). Also, it provides effective control of a wide range of lepidopteran insects. The chemical upon absorption into the haemolymph of the insect, binds to the ecdysone receptor which initiates the moulting process. As the normal process disrupted, the insects prevented from shedding its old cuticle. The larvae die of dehydration and starvation within 25 days (Kumar and Santharam, 2008).

Pyridalyl exhibit high insecticidal activity against Lepidoptera (Sakamoto et al., 2003). It posses a certain type of toxicity for insect cells, it inhibited the cell growth (Satio et al., 2006).

The main target of this study is to compare the insecticidal efficacy of novel insecticides (emamectin benzoate, methoxyfenozide, and pyridalyl) with the conventional insecticide (methomyl) through assessment of ovicidal and larvicidal effects on laboratory and field strains of S. littoralis and to show the joint action of mixed emamectin benzoate with different groups of insecticides on the laboratory strain under laboratory conditions.

\section{MATERIALS AND METHODS}

\section{Insect rearing:}

a.The laboratory strain of Spodoptera littoralis was provided from the division of cotton leafworm of Plant Protection Research Institute, Dokki, Egypt. The laboratory strain was reared in the laboratory of Sakha Agricultural Research Station on castor bean leaves. The egg masses were collected daily and they were hatched on the oleander leaves. The larvae were transferred to fresh castor oil leaves. The colony was kept at a temperature of $25 \pm 2^{\circ} \mathrm{C}$ and $65 \pm 5 \%$ relative humidity (El-Defrawi et al., 1964).

b. The field strain was obtained by the collection of the egg masses from cotton plants at the Sakha Agricultural Research Station before the start of the chemical control programme. The eggs were allowed to hatch and the insect rearing continued for one generation according to the previous method.

\section{Insecticides used:}

Emamectin benzoate (Proclaim 5\% SG) was produced by Syngenta Co., methoxyfenozide (Runner 24\% SC) was produced by Dow AgroSciences Co., pyridalyl (Pleo 50\% EC) was produced by Sumitomo Chemical Co., and methomyl (Lannate $90 \%$ SP) was produced by DuPont Co.

\section{Bioassay studies:}

\section{a. Ovicidal activity:}

Freshly deposited egg-masses from a laboratory strain of S. littoralis were collected daily for three successive days to represent egg-masses having the ages (0-24 hrs) for these laid in the third day, (24-48 hrs) in the second day and (48-72 hrs) in the first day, which were all treated at the third day. The egg-masses were dipped for 10 seconds in different water dilutions of the tested compounds. The untreated eggs were dipped in water. Three replicates were used with each concentration. Treated and untreated egg- 
masses were left to dry, placed in plastic cups and kept at $25 \pm 2^{\circ} \mathrm{C}, 65 \pm 5 \%$ relative humidity. Hatched and unhatched eggs were examined 2-4 days after the test (after maximum hatch in the control check). The percent of unhatchability for each treatment adjusted by compared with the control treatment by Abbott's formula (1925) and the LC $_{50}$ values were calculated according to (Finney, 1971) using « LC-p Line » software.

\section{b. Larvicidal activity:}

Leaf dip was adopted to estimate the toxicity of methomyl, pyridalyl, emamectin benzoate and methoxyfenozide to $S$. littoralis larvae. Castor bean leaves were dipped for 10 seconds in aqueous dilution of the mentioned formulated toxicants. The treated leaves were offered to the $4^{\text {th }}$ larval instar of field and laboratory strains, after being left to dry. Serial concentrations of each toxicant were used for the establishment of the LC-P Line. Five replicates with 10 larvae were used for each concentration. The larvae were allowed to feed on treated leaves for 24 hours. Meanwhile control larvae were feed on untreated castor leaves for 24 hours. Mortality counts were recorded after 24 hours post-treatment for methomyl and pyridalyl and after 24, 48 and 72 hours post-treatment for emamectin benzoate and methoxyfenozide according to (Anonymous, 1967). Mortality data were corrected by Abbott's formula (1925) and the LC $_{50}$ values were calculated according to (Finney, 1971) using « LC-p Line » software.

\section{c. Joint toxic action:}

To test the joint action effect of paired combinations of the tested pesticides, mixtures of tested insecticides were prepared by blending insecticides in proportion to their toxicity equivalent portions of one insecticide with the complementary portions of the other to give the expected $\mathrm{LC}_{50}$. Leaves of castor bean were immersed in each pesticide mixture for 10 seconds and mortality percentages were assessed after 1, 2 and 3 days posttreatment. Each pesticide formulation was also tested alone at $\mathrm{LC}_{25}$ level. The joint toxic action of the different pairs of insecticides was evaluated by the following equation (Mansour et al., 1966):

co - toxictty factor $=\frac{\text { observed \% mortality }- \text { Expected \% mortality }}{\text { Fxpented } \% \text { martality }} \times 100$

The factor was used to differentiate the results into 3 categories. A positive factor $(+20$ or more) meant potentiation, a negative factor $(-20$ or more) meant antagonism, and intermediate value between $(-20$ and +20$)$ was considered only an additive effect.

\section{RESULTS AND DISCUSSION}

One of our objectives in this investigation was the evaluation of the ovicidal action of emamectin benzoate compared with another compounds from different chemical groups such as; methoxyfenozide, methomyl and pyridalyl against 0-24 hours, 24-48 hours and 48-72 hours old eggs of $S$. littoralis. According to the results on (0-24, $24-48$ and $48-72$ hours old) eggs 
masses (Tables 1, 2 and 3) data of hatchability showed that emamectin benzoate was superior an ovicidal activity where the $L C_{50}$ values were 10.94 , 11.90 and 12.25 ppm followed by methomyl where $L_{50}$ values were 27.33, 41.24 and $83.26 \mathrm{ppm}$. Methoxyfenozide and pyridalyl was the lowest effect $\left(\mathrm{LC}_{50}\right.$ values were 250.46, 188.33\& 179.82 and 206.30, 202.54 and 175.10 ppm, respectively). These findings are in full agreement with Hassan (2009), who found that three day old eggs are more affected than that of one or two days old in case of indoxacarb and spinetoram while the reverse was in the case of methoxyfenozide. Moreover, Kotb (2011) mentioned that the emamectin benzoate at concentrations of 3.75, 7.50, 15.0 and $30.0 \mathrm{ppm}$ caused $35.7,50.0,53.9$ and $66.9 \%$ mortality of treated eggs, respectively. In addition, the residues of the same tested concentrations of emamectin benzoate against egg masses caused $100 \%$ mortality for all neonates (the newly hatched larval from those treated eggs). Also, Amer et al. (2012) found that the ovicidal action of the two tested compounds (emamectin benzoate and pyridalyl) against different egg ages of the pink bollworm could be ascendingly arranged as follows: $1,2,3$ and 4 day old. The corresponding $\mathrm{LC}_{50}$ values were, 659.8, 1473.4, 1652.7and $1788.4 \mathrm{ppm}$, respectively for emamectin benzoate and 72.1, 362.8, 817.3 and 7772.4 ppm, ppm, respectively for pyridalyl. It is obvious that the ovicidal activity of the two tested products was increased with egg ages. On the other hand, the ovicidal action of the tested compounds was differed with the different egg ages.

Table (1): Ovicidal activity of emamectin benzoate, methoxyfenozide, methomyl and pyridalyl on S. littoralis eggs (age, 0-24 hrs).

\begin{tabular}{|c|c|c|c|c|}
\hline \multirow{2}{*}{ Insecticides } & \multirow{2}{*}{$\begin{array}{c}L^{L} C_{50} \\
(p p m)\end{array}$} & \multicolumn{2}{|c|}{$95 \% \mathrm{FL}^{\mathrm{a}}$ of $\mathrm{LC}_{50}$} & \multirow{2}{*}{ Slope \pm SE } \\
\hline & & Lower & Upper & \\
\hline Emamectin benzoate & 10.94 & 8.55 & 13.31 & $1.39 \pm 0.18$ \\
\hline Methoxyfenozide & 250.46 & 169.42 & 356.75 & $0.82 \pm 0.23$ \\
\hline Methomyl & 27.33 & 24.85 & 29.74 & $2.12 \pm 0.08$ \\
\hline Pyridalyl & 206.30 & 180.69 & 231.14 & $2.44 \pm 0.25$ \\
\hline
\end{tabular}

$\mathrm{FL}^{\mathrm{a}}$ : Fiducial limit.

Tble (2): Ovicidal activity of emamectin benzoate, methoxyfenozide, methomyl and pyridalyl on S. littoralis eggs (age, 24-48 hrs).

\begin{tabular}{|c|c|c|c|c|}
\hline \multirow{2}{*}{ Insecticides } & \multirow{2}{*}{$\begin{array}{c}L_{C_{50}} \\
(p p m)\end{array}$} & \multicolumn{2}{|c|}{$95 \% \mathrm{FL}^{\mathrm{a}}$ of $\mathrm{LC}_{50}$} & \multirow[b]{2}{*}{ Slope \pm SE } \\
\hline & & Lower & Upper & \\
\hline Emamectin benzoate & 11.90 & 10.09 & 13.74 & $1.94 \pm 0.19$ \\
\hline Methoxyfenozide & 188.33 & 165.49 & 209.96 & $2.69 \pm 0.26$ \\
\hline Methomyl & 41.24 & 35.72 & 46.75 & $1.40 \pm 0.08$ \\
\hline Pyridalyl & 202.54 & 175.38 & 228.64 & $2.27 \pm 0.25$ \\
\hline
\end{tabular}

$\mathrm{FL}^{\mathrm{a}}$ : Fiducial limit. 
Table (3): Ovicidal activity of emamectin benzoate, methoxyfenozide, methomyl and pyridalyl on S. littoralis eggs (age, 48-72 hrs).

\begin{tabular}{|l|c|c|c|c|}
\hline \multirow{2}{*}{ Insecticides } & \multirow{2}{*}{$\begin{array}{c}\mathbf{L C}_{\mathbf{5 0}} \\
\mathbf{p p m})\end{array}$} & \multicolumn{2}{|c|}{$\mathbf{9 5 \%} \mathbf{F L}^{\mathbf{a}}$ of $\mathbf{L C}_{\mathbf{5 0}}$} & \multirow{2}{*}{ Slope $\pm \mathbf{S E}$} \\
\cline { 3 - 4 } & 12.25 & 10.07 & 14.48 & $1.61 \pm 0.18$ \\
\hline Emamectin benzoate & 179.82 & 160.29 & 198.32 & $3.17 \pm 0.27$ \\
\hline Methoxyfenozide & 83.26 & 68.19 & 101.58 & $1.37 \pm 0.14$ \\
\hline Methomyl & 175.10 & 146.99 & 200.71 & $2.13 \pm 0.24$ \\
\hline Pyridalyl
\end{tabular}

$\mathrm{FL}^{\mathrm{a}}$ : Fiducial limit

Concerning the effect of the aforementioned insecticides against the $4^{\text {th }}$ instar larvae of lab. and field strains. Data illustrated in Table (4) showed that emamectin benzoate was the high toxic against $4^{\text {th }}$ instar larvae of laboratory strain. The $L^{2} C_{50}$ values were 0.019 and $0.007 \mathrm{ppm}$ after 48 and $72 \mathrm{hrs}$, respectively. While, Pyridalyl was the second one, the $\mathrm{LC}_{50}$ value was 18.679 ppm after $24 \mathrm{hrs}$. Whereas, methoxyfenozide was the third one, its $\mathrm{LC}_{50}$ values were 20.576 and $0.932 \mathrm{ppm}$ after 48 and $72 \mathrm{hrs}$, respectively. Methomyl was the fourth one, its $\mathrm{LC}_{50}$ value was $95.604 \mathrm{ppm}$ after $24 \mathrm{hrs}$.

Also, data in Table (5) revealed that emamectin benzoate was the most toxic one against $4^{\text {th }}$ instar larvae of field strain. The $L C_{50}$ values were 0.039 and $0.020 \mathrm{ppm}$ after 48 and $72 \mathrm{hrs}$, respectively. While, methoxyfenozide was the second one, the $\mathrm{LC}_{50}$ values were 33.313 and $5.564 \mathrm{ppm}$ after 48 and $72 \mathrm{hrs}$, respectively. Whereas, pyridalyl was the third one, its $\mathrm{LC}_{50}$ value was $35.549 \mathrm{ppm}$ after $24 \mathrm{hrs}$. While, methomyl was the fourth one, its LC $_{50}$ value was $562.073 \mathrm{ppm}$ after $24 \mathrm{hrs}$. These results are in agreement with those obtained by Adamczyk et al. (1999), they reported that novel insecticides chlorfenapyr, methoxyfenozide, spinosad and tebufenozide were more toxic than conventional insecticide thiodicarb toward the third instar larvae of fall armyworm, $S$. frugiperda using diet bioassay. Moreover, Argentine et al. (2002) found that the emamectin benzoate was consistently the most toxic insecticide; it was 20-to 64.240-times more toxic than chlorfenapyr, fipronil and tebufenozide. Moreover, El-Aw (2003), mentioned that the bioinsecticide (proclaim) against $2^{\text {nd }}$ instar larvae was more toxic than the $4^{\text {th }}$ instar larvae of $S$. littoralis. Increases in larval mortalities of both instars were clearly observed for 120 hrs posttreatment. Mortalities that recorded at $120 \mathrm{hrs}$ posttreatment with low proclaim concentration (5 ppm) were $70 \%$ and $50 \%$ for the $2^{\text {nd }}$ and $4^{\text {th }}$ instars, respectively. It is clear that larval mortalities were increased not only by increase proclaim concentrations but also by increase in days posttreatment. Pineda et al. (2004), who reported that spinosad and methoxyfenozide were potentially potent compounds for the control of S. littoralis. Ahmad et al. (2005), mentioned that emamectin benzoate proved to be the best followed by lufenuron, spinosad and indoxacarb, respectively in their time-oriented mortality at three concentration levels tested. Satio et al. (2005) mentioned that pyridalyl caused $100 \%$ mortality in the $4^{\text {th }}$ instar larvae of S. litura at concentration of $500 \mathrm{mg} / \mathrm{L}$. Also, El-Aw (2006), found that the LC $_{50}$ values of emamectin 
benzoate and spinosad were decreased, in general, by increasing the posttreatment period of times. Abdu-Allah (2010) found that emamectin benzoate had the best toxicity profile in all tested bioassay than spinetoram. In another study, Dahi et al. (2011) found that pyridalyl is more effective on $4^{\text {th }}$ instar larvae due to the larval mortality percent estimated by $78.0 \%$. Also, Kotb (2011) mentioned that emamectin benzoate was more toxic against the $2^{\text {nd }}, 3^{\text {rd }}$ and $4^{\text {th }}$ instar larvae of cotton leafworm than lufenuron and flufenoxuron.

Data presented in Table (6) showed that the level of resistance ratio of the $4^{\text {th }}$ instar larvae of $S$. littoralis laboratory and field strains against tested insecticides. The level of resistance on the field strain for methoxyfenozide and methomyl were $(1.6,5.9)$ and 5.8 fold as the laboratory strain, these results indicated that the field strain became tolerant. On the other hand, the resistance level of emamectin benzoate and pyridalyl on the field strain were $(1.9,2.7)$ and 1.9 fold as the laboratory strain. These results showed that all tested insecticides are still effective in the control of $S$. littoralis.

Table (4): LC $_{50}$ values of emamectin benzoate, methoxyfenozide, methomyl and pyridalyl against $4^{\text {th }}$ instar larvae of Lab. strain of S. littoralis.

\begin{tabular}{|c|c|c|c|c|c|c|}
\hline \multirow{2}{*}{ Insecticides } & \multirow{2}{*}{$\begin{array}{c}\text { Times } \\
\text { (hrs) }\end{array}$} & \multirow{2}{*}{$\begin{array}{c}\mathbf{L C}_{50} \\
\text { (ppm) }\end{array}$} & \multicolumn{2}{|c|}{$95 \% \mathrm{FL}$ of $\mathrm{LC}_{50}$} & \multirow{2}{*}{ Slope \pm SE } & \multirow{2}{*}{$\mathbf{X}^{2 * *}$} \\
\hline & & & Lower & Upper & & \\
\hline \multirow{2}{*}{ Emamectin benzoate } & 48 & 0.019 & 0.015 & 0.036 & $1.58 \pm 0.37$ & 2.43 \\
\hline & 72 & 0.007 & 0.005 & 0.009 & $1.60 \pm 0.33$ & 5.55 \\
\hline \multirow[b]{2}{*}{ Methoxyfenozide } & 48 & 20.576 & 8.824 & 45.729 & $0.51 \pm 0.122$ & 1.95 \\
\hline & 72 & 0.932 & 0.028 & 2.839 & $0.60 \pm 0.172$ & 2.24 \\
\hline Methomyl & 24 & 95.604 & 75.532 & 123.667 & $2.25 \pm 0.28$ & 3.91 \\
\hline Pyridalyl & 24 & 18.679 & 12.614 & 26.005 & $1.38 \pm 0.22$ & 9.43 \\
\hline
\end{tabular}

FL: Fiducial limit. ${ }^{\star *} \mathrm{X}^{2}:$ Chi square.

Table (5): LC $_{50}$ values of emamectin benzoate, methoxyfenozide, methomyl and pyridalyl against $4^{\text {th }}$ instar larvae of field Strain of S. littoralis.

\begin{tabular}{|c|c|c|c|c|c|c|}
\hline \multirow{2}{*}{ Insecticides } & \multirow{2}{*}{\begin{tabular}{|c|} 
Times \\
(hrs)
\end{tabular}} & \multirow{2}{*}{$\begin{array}{c}\text { LC }_{50} \\
\text { (ppm) }\end{array}$} & \multicolumn{2}{|c|}{ 95\% F.L. of $L^{*} C_{50}$} & \multirow{2}{*}{ Slope \pm SE } & \multirow{2}{*}{$X^{2 * *}$} \\
\hline & & & Lower & Upper & & \\
\hline \multirow{2}{*}{ Emamectin benzoate } & 48 & 0.039 & 0.033 & 0.058 & $3.52 \pm 0.84$ & 1.54 \\
\hline & 72 & 0.020 & 0.016 & 0.022 & $3.49 \pm 0.75$ & 1.07 \\
\hline \multirow{2}{*}{ Methoxyfenozide } & 48 & 33.313 & 21.586 & 49.394 & $1.11 \pm 0.17$ & 1.02 \\
\hline & 72 & 5.564 & 1.625 & 10.676 & $0.09 \pm 0.17$ & 1.50 \\
\hline Methomyl & 24 & 562.073 & 340.521 & 1216.972 & $0.92 \pm 0.15$ & 0.79 \\
\hline Pyridalyl & 24 & 35.549 & 21.467 & 56.018 & $1.13 \pm 0.25$ & 2.02 \\
\hline
\end{tabular}

${ }^{*}$ FL: Fiducial limit. $\quad{ }^{* *} \mathbf{X}$ : Chi square. 
Table (6): Resistance ratio of $4^{\text {th }}$ instar larvae of $S$. littoralis laboratory and field strains against tested insecticides.

\begin{tabular}{|c|c|c|c|c|c|c|c|}
\hline \multirow[b]{2}{*}{ Insecticides } & \multirow[b]{2}{*}{ Strain } & \multirow{2}{*}{$\begin{array}{l}\text { Time } \\
\text { (hrs) }\end{array}$} & \multirow[b]{2}{*}{$\mathrm{LC}_{50}$} & \multicolumn{2}{|c|}{$95 \% \mathrm{FL}^{\mathrm{a}}$ of $\mathrm{LC}_{50}$} & \multirow[b]{2}{*}{ Slope \pm SE } & \multirow[b]{2}{*}{$\mathbf{R R}^{\mathrm{k}}$} \\
\hline & & & & \begin{tabular}{|l|} 
Lower \\
\end{tabular} & Upper & & \\
\hline \multirow{4}{*}{$\begin{array}{l}\text { Emamectin } \\
\text { benzoate }\end{array}$} & Lab. & 48 & 0.020 & 0.014 & 0.036 & $1.58 \pm 0.37$ & 1.9 \\
\hline & Field & 48 & 0.039 & 0.033 & 0.058 & $3.52 \pm 0.84$ & \\
\hline & Lab. & 72 & 0.007 & 0.005 & 0.009 & $1.60 \pm 0.33$ & 2.7 \\
\hline & Field & 72 & 0.020 & 0.016 & 0.022 & $3.49 \pm 0.75$ & \\
\hline \multirow{4}{*}{ Methoxyfenozide } & Lab. & 48 & 20.576 & 8.824 & 45.729 & $0.51 \pm 0.12$ & 1.6 \\
\hline & Field & 48 & 33.313 & 21.586 & 49.394 & $1.11 \pm 0.17$ & \\
\hline & Lab. & 72 & 0.932 & 0.028 & 2.839 & $0.60 \pm 0.17$ & 5.9 \\
\hline & Field & 72 & 5.564 & 1.625 & 10.676 & $0.90 \pm 0.17$ & \\
\hline \multirow{2}{*}{ Methomyl } & Lab. & 24 & 95.604 & 75.532 & 123.667 & $2.25 \pm 0.28$ & 5.8 \\
\hline & Field & 24 & 562.073 & 340.521 & 1216.972 & $0.92 \pm 0.15$ & \\
\hline \multirow{2}{*}{ Pyridalyl } & Lab. & 24 & 18.679 & 12.615 & 26.005 & $1.38 \pm 0.22$ & 1.9 \\
\hline & Field & 24 & 35.549 & 21.467 & 56.018 & $1.13 \pm 0.25$ & \\
\hline
\end{tabular}

$\mathrm{FL}^{\mathrm{a}}$ : Fiducial limit. $\quad$ R. $\mathrm{R}^{\mathrm{b}}$ : resistance ratio $=\mathrm{LC}_{50}$ of field strain $/ \mathrm{LC}_{50}$ of laboratory strain

Results in Table (7) showed the joint toxic action of binary insecticides mixtures on the $4^{\text {th }}$ instar larvae of cotton leafworm after 24,48 and 72 hrs post-treatment. Generally, all mixtures of the tested insecticides showed highly antagonisms effect except emamectin benzoate + methoxyfenozide after $24 \mathrm{~h}$ of exposure was potentiation effect. The calculated Co-toxicity factors (CTF) of emamectin benzoate $\left(\mathrm{LC}_{25}\right)$ with methoxyfenozide, methomyl and pyridalyl mixture were $-65.52,-83.33$ and -60.00 after $72 \mathrm{hrs}$ of exposure. The Co-toxicity factors of the methoxyfenozide $\left(\mathrm{LC}_{25}\right)$ with methomyl and pyridalyl mixture were -65.53 and -57.16 after $72 \mathrm{hrs}$ of treatment. On the other hand, The Co-toxicity factors of the methomyl $\left(\mathrm{LC}_{25}\right)$ with pyridalyl mixture were -79.6 after $72 \mathrm{hrs}$ of exposure. From these data, the emamectin benzoate, methoxyfenozide, methomyl and pyridalyl mixtures should not be used. These results are confirmed by Kotb (2011), who found that the mixtures of emamectin benzoate and lufenuron or flufenoxuron showed antagonistic effects.

Overall, our results show the emamectin benzoate may be considered a valuable tool for the control of cotton leafworm as a component of IPM programme. 
Saleh, A. A. et al.

7- 


\section{REFERENCES}

Abbott, W.S. (1925). A method for computing the effectiveness of an insecticide. J. Econ. Entomol., 18: 265-267.

Abdu-Allah, G.A.M. (2010). Laboratory and field evaluation of emamectinbenzoate and spinetoram on cotton leafworm larvae. Resistant Pest Management Newsletter. 20(1): 13-17.

Adamczyk, J . J.; J . R. Leonard and J . B. Graves (1999). Toxicity of selected insecticides to fall armyworms (Lepidoptera: Noctuidae) in laboratory bioassay studies. Florida. Entomol., 82(2): 230-236.

Ahmad, M.; M.A. Saleem and M.Ahmad (2005). Time- oriented mortalityin leafworm, Spodoptera litura (FAB.) (Lepidoptera: Noctuidae) by some new chemistry insecticides. Pak. Entoml., 27(1): 67-70.

Amer, R.A.M., A. E. Hatem and A.M. Adly (2012). Effect of emamectin benzoate and pyridalyl on some demographic aspects of the pink bollworm, Pectinophora gossypiella (Saunders). Egypt. J. Agric. Res., 90(2): 657-673.

Anonymous, WHO (1967). Specifications for pesticides used in public health. Third Ed., Geneva, pp:300.

Argentine, J.A.; R.K. Jansson; W.R.Halliday; D. Rugg and C. S. Jany (2002). Potency, spectrum and residual activity of four new Insecticides under glass house conditions. Florida. Entomol., 85 (4): 552-562.

Dahi, H .F.; A. S. Kamel; N.M. El-Barkey and M.F. Abd-El Aziz (2011). Pyridalyl effectiveness on some biological and physiological parameters of cotton leafworm Spodoptera littoralis (Boisd.) (Lepidoptera : Noctuidea). J. American. Sci., 7(12): 855-863.

Dhadialla, S. and R.Lep. Carlson (1998). New insecticides with ecdysteroidal and juvenile hormone activity.Ann Rev.Entomol., 43: 545-569.

Dunbar, D.M.; D.S. Lawson; S.M.White; P. Nago Dugger and D.Richter (1998). Emamectin benzoate control of Heliothine complex andimpacton beneficial arthropods. In: Beltwide cotton conference, San Diego, California, Proceedings, USA.V2, PP 1116-1118.

El-Aw, M . A. (2003). Bioassay and sublethal effects of various selected insecticides on some biological aspects of the cotton leafworm, Spodoptera littoralis (Boisd.) (Lepidoptera : Noctuidae). Alex . J . Agric. Res., 48(3): 73-82.

El-Aw, M. A. (2006). Efficacy of two biorational insecticides, emamectin benzoate and spinosad against the immature stages of the cotton leafworm, Spodoptera littoralis (Boisd.) (Lepidoptera: Noctuidae). Alex. J. Agric. Res., 51(1): 55-68.

El-Defrawi, M.E .; A. Toppozade; N. Mansour and M. Zeid (1964). Toxicological studies on the Egyptian cotton leafworm; Prodenia litura: I. Susceptibility of different larval instar of Prodenia to insecticides. J. Econ. Ent., 57: 591-593.

Finney, D.J. (1971). Probit analysis, $3^{\text {rd }}$ Ed. Cambridge Univ. Press, LondonPP: 333. 
Hassan, H.A. (2009). Efficiency of some new insecticides on physiological, histological and molecular level of cotton leafworm. Egypt. Acad. J. biolog. Sci., 2(2): 197-209.

Kotb, E.K.E. (2011). Latent effects of emamectin benzoate for controlling the cotton leafworm Spdoptera littoralis. M. Sc. Thesis. Fac. Agric. Alexandria University.

Kumar, K. and G. Santharam (2008). Toxicity of RH-2485 (Methoxyfenozide 20F) against Helicoverpa armigera (Hub.). Journal of Biopesticides., 1(2): 199-200.

Mansour, N. A.; E. El-Deferawi; A. Toppozada and M. Zeid (1966). Toxicological studies on the Egyptian cotton leafworm, Prodenia litura. 4: potentiation and antagonism of organophosphorus and carbamate insecticides. J. Econ. Entomol., 59: 307-311.

Pineda, S.; F. Budia; M.I. Schneider; A. Gobbi; E. Vinuela; J. Valle and P.D. Estal (2004). Effects of two biorational insecticides Spinosadand Methoxyfenozide on Spodoptera littoralis (Lepidoptera: Noctuidae) under laboratory conditions. J. Econ. Entomol., 97(6): 1906-1911.

Sakamoto, N.; S. Satio; T. Hirose; M. Suzuki; S. Matsuo; K. Izumi; T. Nagatomi; H. Ikegami; K. Umeda; K. Tsushima and N. Matsuo (2003). The discovery of pyridalyl: a novel insecticidal agent forcontrolling lepidopterous pests. Pest Management Sci., 60: 25-34.

Satio, S.; N. Sakamoto and K. Umeda (2005). Effect of pyridalyl a novelinsecticidal agent on cultured Sf9 cells. J. Pestic. Sci., 30(1): 1721.

Satio, S.; T. Yoshiok and U. Kimitoshi (2006). Ultrastructural effects of pyridalyl, an insecticides agent, on epidermal cells of Spodoptera litura larvae and cultural insect cells Sf9. J. Pesticides Sci., 31(3): 335-338. 


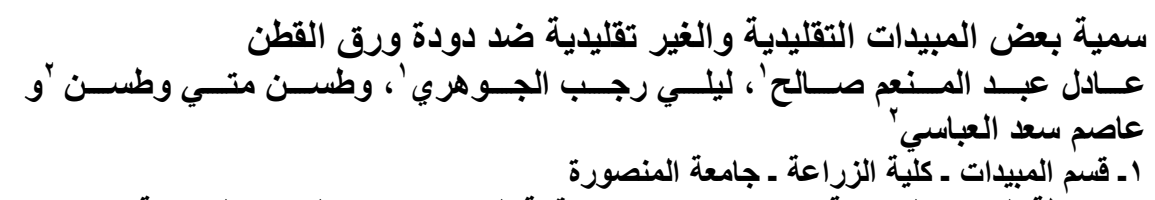

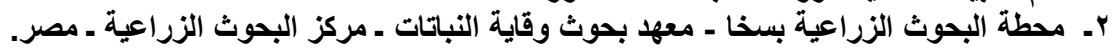

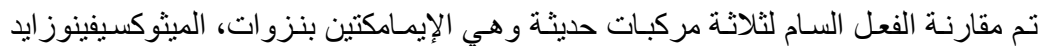

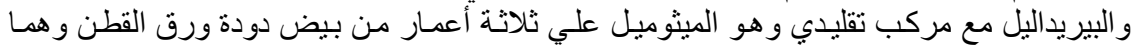

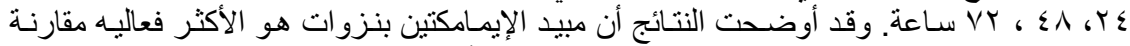

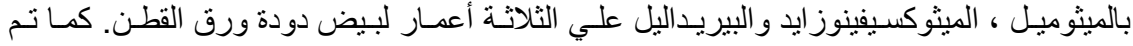

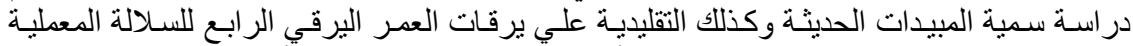

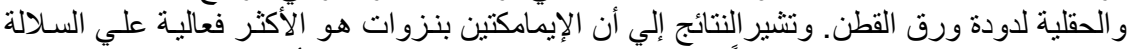

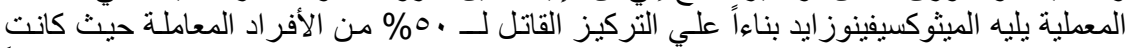

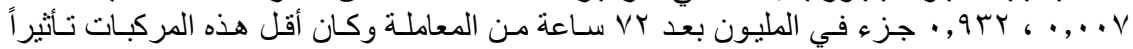

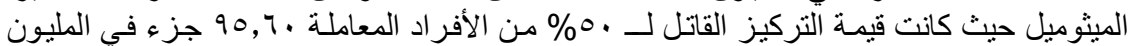

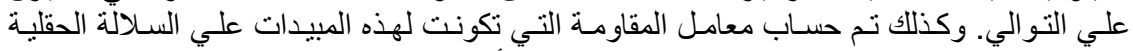

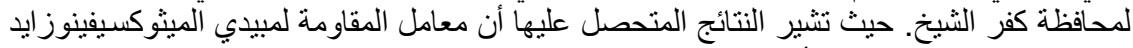

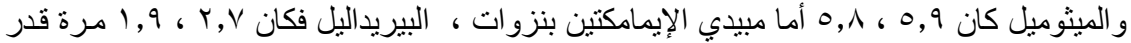

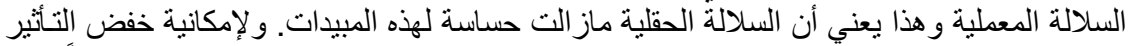

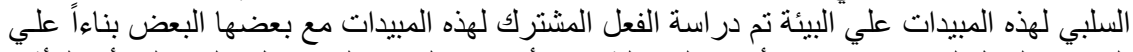



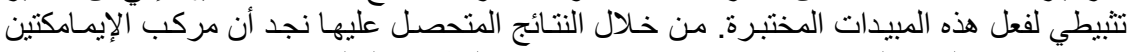

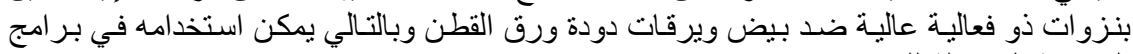






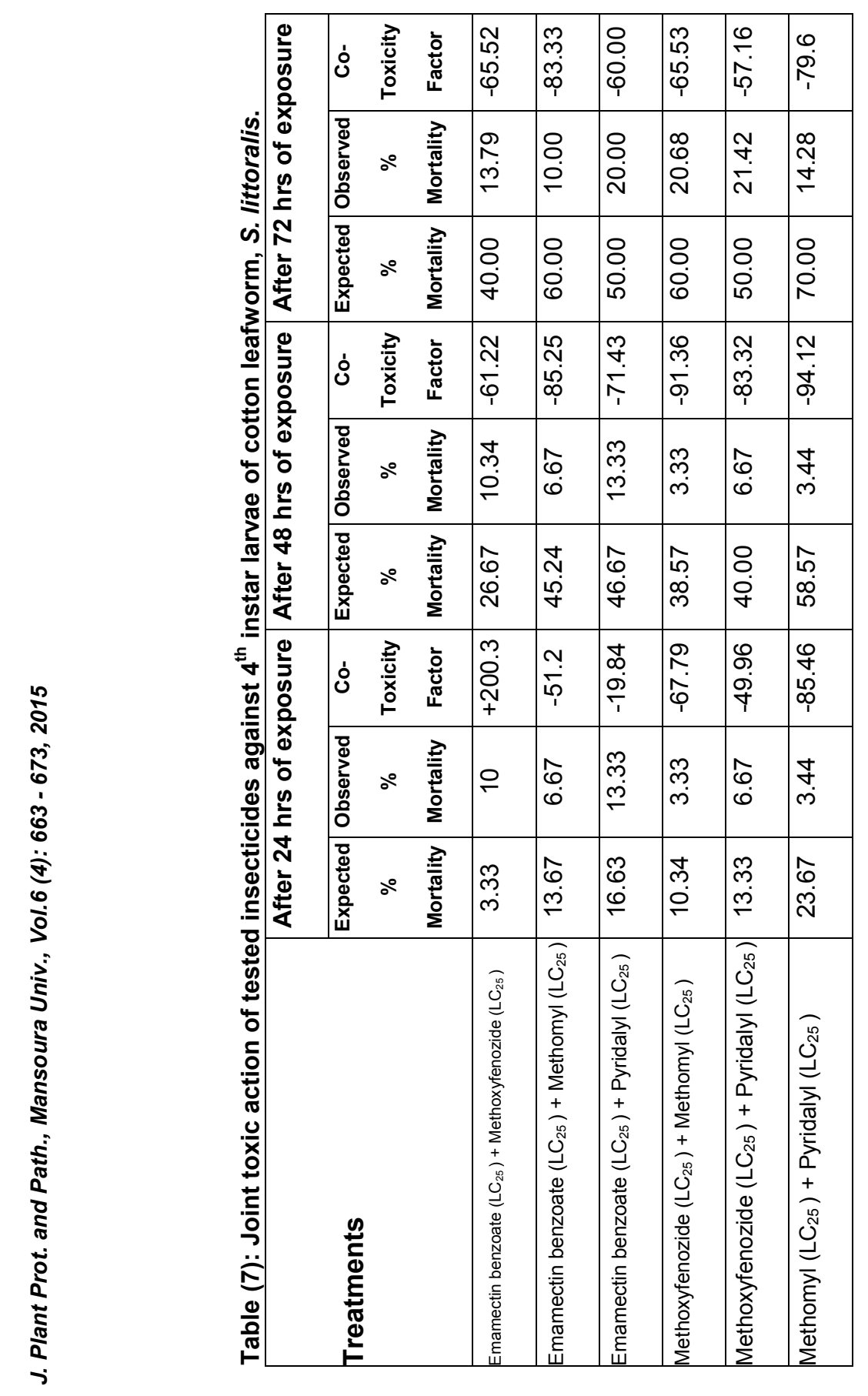

